\title{
Pengukuran Kinerja dengan Metode Balance Scorecard pada Perusahaan Printpro
}

\author{
Yuniaristanto $^{* 1)}$, Irfan Hilmi Hamdani ${ }^{1 \text {, }}$, Niken Aristyawati ${ }^{1)}$, Galuh Qodrina ${ }^{1)}$ \\ ${ }^{1)}$ Program Studi S1 Teknik Industri, Fakultas Teknik, Universitas Sebelas Maret, \\ Jl. Ir. Sutami No.36 Jebres, Surakarta, 57126, Indonesia
}

\begin{abstract}
Performance measurement required by each company to conduct an evaluation of various aspects in order to improve the quality and increase the profit of the company. Performance measurement on Printpro done using the Balanced Scorecard method outlined in the Critical Success Factor or Key Performance Index. As for the weighting of each of these perspectives using Paired comparisson. Of the votes obtained some aspects that increase, constant and decreasing. For increased aspect is learning and growth perspective of the year 2014 amounted to 0.334 into 0.418 in 2015. While the constant perspective is the perspective of the customer from 2014 to 2015 is at a value of 0.84. And for the financial perspective of 2014 decreased by 0.835 into 0.752 in 2015, while the internal business perspective also declined from 0.17 in 2014 to 0.08 in 2015
\end{abstract}

Keywords: Performance Measurement, Balanced Scorecard, Critical Succes Factor, Key Performance Index, Paired Comparisson.

\section{Pendahuluan}

Pengukuran kinerja merupakan salah satu faktor yang penting bagi perusahaan. Hal tersebut dikarenakan dengan pengukuran kinerja dapat dipergunakan sebagai dasar pertimbangan tingkat keberhasilan perusahaan dan juga untuk menyusun sistem imbalan dalam perusahaan. Menurut Lane K. Anderson \& Donald (1991:1008); Yuwono dkk (2008:21), pengukuran kinerja di definisikan bahwa umpan balik yang akan memberikan informasi tentang seberapa baik tindakannya tentang prestasi pelaksanaan suatu rencana dimana perusahaan memerlukan penyesuaian-penyesuaian atas aktivitas perencanaan atas pengendalian. Dari pengukuran tersebut diharapkan mampu memberikan acuan kepada perusahaan untuk bisa melakukan evaluasi secara keseluruhan dalam meningkatkan kualitas dan kapasitas mereka.

Pada studi kasus di perusahaan PrintPro menunjukkan jika pengukuran kinerja secara menyeluruh belum diperhatikan. Orientasi profit menjadi hal utama yang ingin dicapai secara maksimal oleh perusahaan.

Dari tujuan awal, perusahaan memiliki target berupa peningkatan laba secara maksimal. Hanya saja, parameter peningkatan laba saja tidak mencukupi karena faktor pendukung lain pun harus dimaksimlakan seperti pemenuhan kepuasan konsumen, loyalitas konsumen, serta ongkos produksi dan harga pokok produksi yang minimal. Ketiga faktor pendukung tersebut harus dibuat seoptimal mungkin, sehingga tidak memberikan penambahan ongkos atau penghalang bagi maksimalisasi laba.

Di sisi lain, keinginan konsumen selalu menuntut untuk mendapatkan pelayanan dan kebutuhan dengan baik dan harga yang minimal. Hal tersebut mengharuskan perusahaan untuk mengeluarkan biaya atau membuat profit berkurang demi memberikan pelayanan bagi konsumen.

Untuk kondisi aktual pada perusahaan PrintPro sendiri memiliki pesaing dengan jarak dekat sehingga terjadi persaingan sempurna. Cabang dari perusahaan pun sudah cukup tersebar dan bertahan lama. Hanya saja, keuntungan belum bisa dimaksimalkan dengan baik.

\footnotetext{
*Correspondance : Yuniaristanto@gmail.com
} 
Dalam rangka meningkatkan keuntungan yang menjadi orientasi utama dari perusahaan, maka dilakukan pengukuran kinerja sebagai langkah awal untuk meningkatkan profit. Pengukuran kinerja didasarkan pada metode Balance Scorecard. Pengukuran dengan metode tersebut digunakan karena selain mudah dilakukan, dan cocok untuk perusahaan yang kerangka kerja organisasinya belum terlalu jelas, sehingga dapat dilakukan pengukuran dengan baik.

Balanced Scorecard pertama kali diperkenalkan oleh Kaplan dan Norton di Harvard Business Review edisi Januari-Februari (1992:71) yang membahas kerangka berpikir komprehensif mengenai ukuran kinerja untuk mengimplementasikan strategi. Balanced Scorecard terdiri dari dua kata yaitu kartu skor (scorecard) dan berimbang (balanced). Kartu skor digunakan untuk mengukur kinerja seseorang. Kartu skor juga dapat digunakan untuk merencanakan skor yang hendak diwujudkan dimasa depan. Kata berimbang dimaksudkan untuk menunjukkan bahwa kinerja personel diukur secara berimbang dari dua aspek yaitu keuangan dan non keuangan, jangka pendek dan jangka panjang, internal dan eksternal. Oleh karena itu untuk merencanakan skor yang hendak diwujudkan harus memperhitungkan keseimbangan antara pencapaian kinerja keuangan dan non keuangan, kinerja jangka pendek dan jangka panjang, serta yang bersifat internal dan eksternal. Dan juga memandang perusahaan dari empat perspektif: perspektif financial, perspektif pelanggan, perspektif proses bisnis internal dan perspektif pembelajaran dan pertunbuhan yang menghubungkan pengendalian operasional jangka pendek ke dalam visi dan strategi bisnis jangka panjang selanjutnya manajemen didorong untuk memfokuskan diri pada rasio-rasio kunci yang kritis dan strategis.

Balanced Scorecard sebagai alat pengukuran kinerja badan usaha merupakan panduan yang tepat dalam menghadapi persaingan. Adanya hubungan antara pengukuran kinerja dengan strategi dan Critical Success Factor (CSF) serta proses penerapannya yang tidak membutuhkan biaya besar, mengindikasikan bahwa Balanced Scorecard merupakan suatu alat bantu yang ideal bagi pihak manajemen badan usaha saat ini. Suwardi Lubis dan Prima A. Biromo (2009:48) menyatakan Balanced Scorecard memberikan hasil pengukuran kinerja yang menyeluruh baik eksternal maupun internal, karena menggunakan empat sudut pandang yang berbeda yaitu : Financial, pelanggan, proses bisnis internal, pembelajaran dan berkembang membentuk suatu kerangka (frame work) sehingga mampu memberikan pengukuran yang lengkap. Balanced Scorecard melakukan pengukuran kinerja berdasarkan critical success factors sehingga informasi yang dihasilkan terarah dan proses pelaksanaan dapat dipantau tingkat pencapaiannya menggunakan Key Performance Indicator (KPI). Pengukuran kinerja yang digunakan dalam Balanced Scorecard merupakan terjemahan visi dan strategi dari perusahaan, sehingga hasilnya akan relevan dan bermanfaat bagi proses manajemen sistem perusahaan.

\section{Metode Penelitian}

\subsection{Pengukuran Balance Scorecard}

Pada pengukuran ini dibagi dalam empat perspektif berupa financial, pelanggan, proses bisnis internal serta pembelajaran dan pertumbuhan. Scorecard dirancang dengan menetapkan tujuan, tolak ukur strategis yang dipakai, target yang ingin dicapai kriteria penilaian kinerja perusahaan, dan skor penilaian kinerja perusahaan.

Kriteria penilaian kinerja perusahaan secara keseluruhan didasarkan pada nilai 1 untuk kinerja kurang. Sedangkan nilai 2, kinerja perusahaan dianggap cukup. Untuk nilai 3, kinerja perusahaan dianggap baik. Penentuan rentang ini ditentukan oleh perusahaan berdasarkan kinerja perusahaan selama ini dan target yang ingin dicapai oleh perusahaan.

\subsection{Critical Succes Factor}

Setelah membuat rancangan pengukuran kinerja perusahaan menggunakan Balance Scorecard, selanjutnya dilakukan perhitungan untuk mengetahui hasil yang dicapai setiap tolok ukur dari keempat perspektif. Perhitungan ini didasarkan pada Key Performace Indicator yang dirancang sebagai parameter pengukuran bagi setiap perspektif.

a. Perspektif Financial 
Current Ratio

Profit Margin

Operating Ratio

Return on Investment

b. Perspektif Customer

Tingkat Pemerolehan Pelanggan

Tingkat Retensi Pelanggan

Tingkat Kepuasan Pelanggan

Tingkat Profitabilitas Pelanggan

c. Perspektif Internal Business

Tingkat Penjualan Produk Baru

Tingkat Kualitas Bahan Baku

$$
\begin{aligned}
& =\frac{\text { Aktiva Lancar }}{\text { Hutang Lancar }} \times 100 \% \\
& =\frac{\text { Laba Bersih }}{\text { Penjualan }} \times 100 \% \\
& =\frac{\text { HPP }+ \text { Beban Usaha }}{P \text { enjualan Bersih }} \times 100 \% \\
& =\frac{\text { Laba Bersih }}{\text { Penjualan }} \times 100 \%
\end{aligned}
$$

$=\frac{\text { Penjualan Produk Baru }}{\text { Penjualan }} \times 100 \%$ $=\frac{\text { Total Jumlah Bahan Baku yang Baik }}{\text { Total Pembelian Bahan Baku }} \times 100 \%$$$
=\frac{\text { Laba Bersih }}{\text { Pendapatan Bersih }} \times 100 \%
$$

d. Perspektif Pembelajaran dan Pertumbuhan

Kepuasan Karyawan

Retensi Karyawan

Produktifitas Karyawan

$$
\begin{aligned}
& =\frac{\text { Total Skor }}{\text { Jumlah Karyawan X Jumlah Pertanyaan }} \times 100 \% \\
& =\frac{\text { Jumlah Karyawan Keluar }}{\text { Jumlah Karyawan }} \times 100 \% \\
& =\frac{\text { Laba Bersih }}{\text { Jumlah Karyawan }} \times 100 \%
\end{aligned}
$$

\subsection{Pembobotan dengan Paired Comparison}

Pembobotan pada kasus ini adalah dengan menggunakan Paired Comparison. Pada metode ini, pemilik perusahaan diminta untuk melakukan perbandingan antara keempat perspektif sebagai penentuan skala prioritas. Menurut Setiawati (2012), metode ini memiliki kelebihan memaksa minimal constrain pada perilaku responden terutama pada pilihan alternative yang sedikit. Langkah-langkah dalam pemberian bobot bagi masing-masing perspektif, sasaran dan ukuran hasil utamanya adalah :

a. Melakukan perbandingan antara suatu elemen (perspektif, sasaran strategis, dan ukuran hasil) dengan elemen lainnya yang disajikan dalam bentuk tabulasi. Perbandingan dilakukan dengan memberikan nilai pada skala 1 sampai 5. nilai 1 berarti suatu elemen dianggap tidak penting dibandingkan dengan elemen yang menjadi pembandingnya. Nilai 2 berarti suatu elemen dianggap kurang penting jika dibandingkan dengan elemen pembandingnya. Nilai 3 berarti kedua elemen memiliki tingkat kepentingan yang sama. Nilai 4 berarti suatu elemen dianggap lebih penting dibandingkan elemen pembandingnya. Sedangkan nilai 5 berarti suatu elemen sangat penting dibandingkan dengan elemen pembandingnya. Nilai yang telah dipertimbangkan, kemudian diisikan pada sel Aij. Perbandingan antara dua unsur elemen yang sama tidak diberi nilai. Untuk sasaran yang hanya memiliki satu ukuran, maka bobot dari ukuran tersebut disamakan dengan bobot dari sasarannya.

b. Memberikan nilai kebalikan dari perbandingan pada langkah satu untuk mengisi sel Aji, misalnya nilai 2 untuk kebalikan dari nilai 4.

c. Menjumlahkan masing-masing nilai unsur elemen tiap baris dan tiap kolom, kemudian menjumlahkan hasilnya.

d. Melakukan perhitungan bobot untuk masing-masing elemen dengan jumlah total nilai lalu dikalikan dengan 100 persen

\section{Hasil dan Penelitian}

$$
\text { Bobot }=\left(\frac{\sum \mathrm{Ai}}{\sum \sum_{\mathrm{i} j} j}\right) \times 100 \%
$$




\subsection{Identifikasi Key Performance Index (KPI)}

Hasil identifikasi KPI disajikan pada Tabel 1.

Tabel 1. Key Performance Index

\begin{tabular}{|c|c|c|}
\hline Perspektif & Objectives & KPI \\
\hline Financial & $\begin{array}{l}\text { - Kemampuan perusahaan untuk memenuhi } \\
\text { kewajiban Financial jangka pendek } \\
\text { - Kemampuan perusahaan melakukan } \\
\text { penjualan dan pengendalian biaya } \\
\text { operasional. } \\
\text { - } \begin{array}{l}\text { Kemampuan perusahaan mengukur biaya } \\
\text { operasi setiap penjualan }\end{array} \\
\text { - } \begin{array}{l}\text { Kemampuan perusahaan } \\
\text { mengembalikan investasi }\end{array} \\
\end{array}$ & $\begin{array}{l}\text { - Profit Margin } \\
\text { - Operating Ratio } \\
\text { - Return on } \\
\text { Invesment } \\
\end{array}$ \\
\hline Customer & 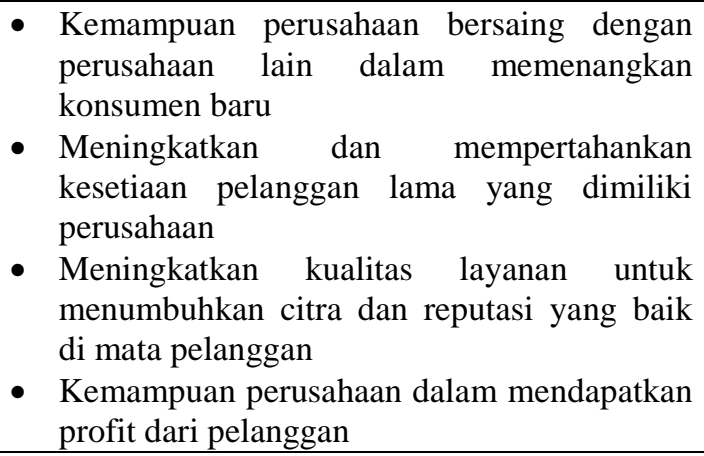 & $\begin{array}{l}\text { - } \text { Tingkat } \\
\text { Pemerolehan } \\
\text { Pelanggan } \\
\text { - Tingkat Retensi } \\
\text { Pelanggan } \\
\text { - Tingkat Kepuasan } \\
\text { Pelanggan } \\
\text { - Tingkat } \\
\text { Profitabilitas } \\
\text { Pelanggan }\end{array}$ \\
\hline $\begin{array}{l}\text { Proses Bisnis } \\
\text { Internal }\end{array}$ & $\begin{array}{l}\text { - Meningkatkan proses pengembangan produk } \\
\text { baru untuk memenuhi keinginan konsumen } \\
\text { dan meningkatkan penjualan. } \\
\text { - Meningkatkan kemampuan perusahaan untuk } \\
\text { menghasilkan produk yang berkualitas. } \\
\text { - Meningkatkan efisensi waktu penerimaan } \\
\text { bahan baku agar tidak mengganggu jadwal } \\
\text { produksi untuk memenuhi pesanan }\end{array}$ & $\begin{array}{l}\text { - } \text { Tingkat Penjualan } \\
\text { Produk Baru } \\
\text { - Tingkat Kualitas } \\
\text { Bahan Baku }\end{array}$ \\
\hline $\begin{array}{l}\text { Pembelajaran dan } \\
\text { Pertumbuhan }\end{array}$ & $\begin{array}{l}\text { - Kemampuan perusahaan untuk menjaga } \\
\text { kepuasan karyawan } \\
\text { - Kemampuan perusahaan untuk } \\
\text { meningkatkan dan mempertahankan } \\
\text { kesetiaan karyawan pada perusahaan }\end{array}$ & $\begin{array}{l}\text { - Kepuasan } \\
\text { Karyawan } \\
\text { - Retensi Karyawan }\end{array}$ \\
\hline
\end{tabular}

\subsection{Perhitungan Critical Succes Factor Tiap Perspektif}

Setelah membuat rancangan Balance Scorecard, langkah selanjutnya adalah melakukan perhitungan untuk setiap KPI yang sudah ditentukan yang mewakili setiap perspektif. Dari perhitungan tersebut akan didapatkan hasil pengukuran kinerja perusahaan selama dua periode yaitu tahun 2014 dan 2015.

Tabel 2. Hasil Pengukuran CSF tiap Perspektif

\begin{tabular}{|c|c|c|c|}
\hline \multirow{2}{*}{ Perspektif } & \multirow{2}{*}{ KPI } & \multicolumn{2}{|c|}{ Tahun } \\
\hline & & 2014 & 2015 \\
\hline \multirow[t]{4}{*}{ Financial } & Current Ratio & $94,08 \%$ & $112,25 \%$ \\
\hline & Profit Margin & $21,10 \%$ & $23,12 \%$ \\
\hline & Operating Ratio & $129,80 \%$ & $125,00 \%$ \\
\hline & Return on Invesment & $13,34 \%$ & $9,01 \%$ \\
\hline \multirow[t]{4}{*}{ Customer } & Tingkat Pemerolehan Pelanggan & $15,10 \%$ & $17,50 \%$ \\
\hline & Tingkat Retensi Pelanggan & $84,90 \%$ & $82,50 \%$ \\
\hline & Tingkat Kepuasan Pelanggan & $87,14 \%$ & $89,15 \%$ \\
\hline & Tingkat Profitabilitas Pelanggan & $71,67 \%$ & $68,47 \%$ \\
\hline Proses Bisnis & Tingkat Penjualan Produk Baru & $8 \%$ & $1 \%$ \\
\hline
\end{tabular}




\begin{tabular}{clcc}
\hline Internal & Tingkat Kualitas Bahan Baku & $96 \%$ & $97 \%$ \\
\hline Pembelajaran & Kepuasan Karyawan & $61 \%$ & $61 \%$ \\
dan Pertumbuhan & Retensi Karyawan & $13 \%$ & $7 \%$ \\
\hline
\end{tabular}

\subsection{Pengukuran Kinerja Perusahaan}

A. Perspektif Financial

Pada perspektif financial ini dilakukan perhitungan nilai Balance Scorecard pada setiap indikator penilaian dalam KPI yang sudah dilakukan. Pada perspektif ni terdiri dari Current Ratio, Profit Margin, Operating Ratio dan nilai ROI.

\section{a. Current Ratio}

Dari nilai Current Ratio dapat diketahui jika kemampuan perusahaan untuk melunasi hutang dalam jangka pendek. Dengan demikian, target yang harus dipenuhi oleh perusahaan adalah sebesar 100\%. Dari perhitungan yang sudah dilakukan, pada tahun 2014, nilai CR sebesar 94,08\%, sedangkan untuk tahun 2015 sebesar 112,25\%. Berdasarkan hal tersebut, maka pada tahun 2014 didapatkan skor sebesar 3 karena mendekati target yaitu sebesar 100\%. Sedangkan pada tahun 2015 didapatkan skor sebesar 3 karena sudah bisa melebihi target.

\section{b. Profit Margin}

Dari nilai Profit Margin dapat diketahui jika kemampuan perusahaan dalam melakukan penjualan dan pengendalian biaya operasional. Dengan demikian, target yang harus dipenuhi oleh perusahaan adalah sebesar 15\%. Dari perhitungan yang sudah dilakukan, pada tahun 2014, nilai PM sebesar 21,01\%, sedangkan untuk tahun 2015 sebesar $23,12 \%$. Berdasarkan hal tersebut, maka pada tahun 2014 didapatkan skor sebesar 3 karena mendekati target yaitu sebesar 15\%. Sedangkan pada tahun 2015 didapatkan skor sebesar 3 karena sudah bisa melebihi target.

c. Operating Ratio

Dari nilai Operating Ratio dapat diketahui jika kemampuan perusahaan untuk mengukur biaya operasi pada setiap penjualan. Semakin kecil nilai OP maka semakin baik. Dengan demikian, target yang harus dipenuhi oleh perusahaan adalah sebesar $85 \%$. Dari perhitungan yang sudah dilakukan, pada tahun 2014, nilai PM sebesar 129,8\%, sedangkan untuk tahun 2015 sebesar 125\%. Berdasarkan hal tersebut, maka pada tahun 2014 didapatkan skor sebesar 2 karena masih jauh target yaitu sebesar $85 \%$. Sedangkan pada tahun 2015 didapatkan skor sebesar 2 karena masih jauh dari target yang ditetapkan.

\section{d. Return on Investment}

Dari nilai Return on Investment dapat diketahui jika kemampuan perusahaan dalam mengembalikan investasi yang dilakukan selama perusahaan melakukan proses bisnis. Semakin kecil nilai ROI maka semakin baik. Dengan demikian, target yang harus dipenuhi oleh perusahaan adalah sebesar $25 \%$. Dari perhitungan yang sudah dilakukan, pada tahun 2014, nilai PM sebesar 19,20\%, sedangkan untuk tahun 2015 sebesar 9,01\%. Berdasarkan hal tersebut, maka pada tahun 2014 didapatkan skor sebesar 2 karena sudah mendekati target yaitu sebesar 25\%. Sedangkan pada tahun 2015 didapatkan skor sebesar 1 karena masih jauh dari target yang ditetapkan.

B. Perspektif Customer

Pada perspektif financial ini dilakukan perhitungan nilai Balance Scorecard pada setiap indikator penilaian dalam KPI yang sudah dilakukan. Pada perspektif ini terdiri dari Tingkat Pemerolehan Pelanggan, Tingkat Retensi Pelanggan, Tingkat Kepuasan Pelanggan dan Tingkat Profitabilitas Pelanggan.

a. Tingkat Pemerolehan Pelanggan

Dari nilai Tingkat Pemerolehan Pelanggan dapat diketahui jika kemampuan perusahaan untuk bersaing dengan perusahaan lain dalam mendapatkan pelanggan baru. Dengan demikian, target yang harus dipenuhi oleh perusahaan adalah sebesar 10\%. Dari perhitungan yang sudah dilakukan, pada tahun 2014, nilai Tingkat Pemerolehan Pelanggan sebesar 15,10\%, sedangkan untuk tahun 2015 sebesar 17,5\%. Berdasarkan hal tersebut, maka pada tahun 2014 didapatkan skor sebesar 3 karena mendekati target yaitu 
sebesar 10\%. Sedangkan pada tahun 2015 didapatkan skor sebesar 3 karena sudah bisa melebihi target.

b. Tingkat Retensi Pelanggan

Dari nilai Tingkat Retensi Pelanggan dapat diketahui jika kemampuan perusahaan dalam mempertahankan dan meningkatkan kesetiaan pelanggan lama. Dengan demikian, target yang harus dipenuhi oleh perusahaan adalah sebesar 100\%. Semakin kecil nilai retensi ini, maka semakin baik, yang artinya terdapat penambahan jumlah pelanggan. Dari perhitungan yang sudah dilakukan, pada tahun 2014, nilai Tingkat Retensi Pelanggan sebesar 84,90\%, sedangkan untuk tahun 2015 sebesar 82,50\%. Berdasarkan hal tersebut, maka pada tahun 2014 didapatkan skor sebesar 3 karena sudah melewati target yaitu sebesar 100\%. Sedangkan pada tahun 2015 didapatkan skor sebesar 3 karena sudah bisa melebihi target.

C. Perspektif Internal Business

Pada perspektif internal business ini dilakukan perhitungan nilai Balance Scorecard pada setiap indikator penilaian dalam KPI yang sudah dilakukan. Pada perspektif ini terdiri dari Tingkat Penjualan Produk Baru.

a. Tingkat Penjualan Produk Baru

Dari nilai Tingkat Penjualan Produk Baru dapat diketahui jika kemampuan perusahaan untuk tingkat penjualan produk baru. Dengan demikian, target yang harus dipenuhi oleh perusahaan adalah sebesar $10 \%$. Dari perhitungan yang sudah dilakukan, pada tahun 2014, nilai Tingkat Penjualan Produk Baru sebesar 8,00\%, sedangkan untuk tahun 2015 sebesar 1,00\%. Berdasarkan hal tersebut, maka pada tahun 2014 didapatkan skor sebesar 2 karena mendekati target yaitu sebesar 10\%. Sedangkan pada tahun 2015 didapatkan skor sebesar 1 karena masih jauh dari target. Pada tahun 2015 memang tidak banyak mengeluarkan produk baru dari PrintPro.

b. Tingkat Kualitas Bahan Baku

Tingkat kualitas bahan baku dihitung berdasarkan perhitungan persentase jumlah bahan baku yang baik yang diperoleh dari Supplier. Target yang harus dipenuhi oleh perusahaan adalah sebesar 95\%. Berdasarkan perhitungan yang dilakukan, pada tahun 2014 besar persentase Tingkat Kualitas Bahan Baku sebesar 96\%, sedangkan pada tahun 2015 sebesar 97\%. Sehingga dapat dikatakan bahwa skor pada tahun 2014 sebesar 2 dan skor pada tahun 2015 sebesar 3. Nilai tersebut menunjukan bahwa pemilihan supplier sudah tepat karena selama dua tahun terakhir memberikan pelayanan yang memuaskan pada PrintPro, hal tersebut ditunjukan dengan jumlah produk cacat yang sangat kecil.

D. Perspektif Pembelajaran dan Pertumbuhan

Pada perspektif pembelajaran dan pertumbuhan ini dilakukan perhitungan nilai Balance Scorecard pada setiap indikator penilaian dalam KPI yang sudah dilakukan. Pada perspektif ini terdiri dari Tingkat Kepuasan Karyawan, Retensi Karyawan dan Produktivitas Karyawan.

a. Tingkat Kepuasan Karyawan

Dari nilai Tingkat Kepuasan Karyawan dapat diketahui jika kemampuan perusahaan untuk Kemampuan perusahaan untuk menjaga kepuasan karyawan. Dengan demikian, target yang harus dipenuhi oleh perusahaan adalah sebesar 85\%. Dari perhitungan yang sudah dilakukan, pada tahun 2014, nilai Tingkat Kepuasan Karyawan sebesar 61\%, sedangkan untuk tahun 2015 sebesar 61\%. Berdasarkan hal tersebut, maka pada tahun 2014 didapatkan skor sebesar 2 karena masih jauh dari target yaitu sebesar $85 \%$. Sedangkan pada tahun 2015 didapatkan skor sebesar 2 karena masih belum mendekati target.

b. Tingkat Retensi Karyawan

Dari nilai Tingkat Retensi Karyawan dapat diketahui jika kemampuan perusahaan dalam mempertahankan dan meningkatkan kesetiaan retensi karyawan. Dengan demikian, target yang harus dipenuhi oleh perusahaan adalah sebesar 6\%. Semakin kecil nilai retensi ini, maka semakin baik, yang artinya tingkat turn over karyawan kecil. Dari perhitungan yang sudah dilakukan, pada tahun 2014, nilai Tingkat Retensi Karyawan sebesar 13,33\%, sedangkan untuk tahun 2015 sebesar 6,67\%. Berdasarkan hal tersebut, 
maka pada tahun 2014 didapatkan skor sebesar 2 karena belum memenuhi target yaitu sebesar 6\%. Sedangkan pada tahun 2015 didapatkan skor sebesar 3 karena sudah sesuai dengan target.

\subsection{Pengukuran Kinerja Perusahaan Secara Keseluruhan}

Perbandingan nilai kinerja pada setiap perspektif dan keseluruhan untuk tahun 2014 dan 2015 menggunakan pembobotan dengan metode Paired Comparisson. Dari pembobotan ini dapat diketahui tingkat kepentingan dari setiap perspektif. Dari perspektif financial didapatkan bobot $28,9 \%$. Untuk perspektif pelanggan pun mendapatkan bobot $28,9 \%$. Sedangkan perspektif pembelajaran dan pertumbuhan mendapatkan bobot 23,6\%. Dan untuk perspektif bisnis internal didapatkan bobot $18,42 \%$. Berikut adalah hasil skor dari setiap perspektif.

Tabel 3. Skor Perspektif Keuangan

\begin{tabular}{|l|r|r|r|r|r|}
\hline & \multicolumn{2}{|c|}{ Komparasi } & Pembobotan & \multicolumn{2}{|c|}{ Hasil } \\
\cline { 2 - 3 } Perspektif Keuangan & 2014 & 2015 & & 2014 & 2015 \\
\hline Current Ratio & 3 & 3 & & 0,251 & 0,251 \\
\hline Profit Margin & 3 & 3 & $29 \%$ & 0,251 & 0,251 \\
\hline Operating Ratio & 2 & 2 & & 0,167 & 0,167 \\
\hline ROI & 2 & 1 & & 0,167 & 0,084 \\
\hline \multicolumn{3}{|c|}{ Hasil } & 0,835 & 0,752 \\
\hline
\end{tabular}

Tabel 4. Skor Perspektif Pelanggan

\begin{tabular}{|c|c|c|c|c|c|}
\hline \multirow{2}{*}{ Perspektif Pelanggan } & \multicolumn{2}{|c|}{ Komparasi } & \multirow[t]{2}{*}{ Pembobotan } & \multicolumn{2}{|c|}{ Hasil } \\
\hline & 2014 & 2015 & & 2014 & 2015 \\
\hline Tingkat Pemerolehan Pelanggan & 3 & 3 & \multirow{4}{*}{$\frac{3}{3} \frac{3}{2}$} & 0,251 & 0,251 \\
\hline Tingkat Retensi Pelanggan & 3 & 3 & & 0,251 & 0,251 \\
\hline Tingkat Kepuasan Pelanggan & 2 & 2 & & 0,167 & 0,167 \\
\hline Tingkat Profitabilitas Pelanggan & 2 & 2 & & 0,167 & 0,167 \\
\hline \multicolumn{4}{|l|}{ Hasil } & 0,84 & 0,84 \\
\hline
\end{tabular}

Tabel 5. Skor Perspektif Pembelajaran dan Pertumbuhan

\begin{tabular}{|l|r|r|r|r|r|}
\hline \multirow{2}{*}{$\begin{array}{c}\text { Perspektif Pembelajaran dan } \\
\text { Pertumbuhan }\end{array}$} & \multicolumn{2}{|c|}{ Komparasi } & \multirow{2}{*}{ Pembobotan } & \multicolumn{2}{|c|}{ Hasil } \\
\cline { 2 - 4 } \cline { 5 - 6 } & 2014 & 2015 & & 2014 & 2015 \\
\hline Kepuasan Karyawan & 2 & 2 & \multirow{2}{*}{$24 \%$} & 0,167 & 0,167 \\
\hline Retensi Karyawan & 2 & 3 & & 0,167 & 0,251 \\
\hline \multicolumn{3}{|c|}{ Hasil } & & 0,334 & 0,418 \\
\hline
\end{tabular}

Tabel 6. Skor Perspektif Bisnis Internal

\begin{tabular}{|l|c|c|c|c|c|}
\hline \multirow{2}{*}{ Prespektif Bisnis Internal } & \multicolumn{2}{|c|}{ Komparasi } & \multirow{2}{*}{ Pembobotan } & \multicolumn{2}{|c|}{ Hasil } \\
\cline { 2 - 3 } & $\mathbf{2 0 1 4}$ & $\mathbf{2 0 1 5}$ & & $\mathbf{2 0 1 4}$ & $\mathbf{2 0 1 5}$ \\
\hline Tingkat Penjualan Produk Baru & 2 & 1 & \multirow{2}{*}{$18 \%$} & 0,167 & 0,084 \\
\hline Tingkat Kualitas Bahan Baku & 3 & 3 & & 0,251 & 0,251 \\
\hline \multicolumn{3}{|c|}{ Hasil } & 0,418 & 0,335 \\
\hline
\end{tabular}

Tabel 7. Rekapitulasi Perspektif
\begin{tabular}{|l|c|c|}
\hline Perspektif & $\mathbf{2 0 1 4}$ & $\mathbf{2 0 1 5}$ \\
\hline Perspektif Keuangan & 0,835 & 0,752 \\
\hline Perspektif Pelanggan & 0,835 & 0.835 \\
\hline Perspektif Pembelajaran dan Pertu & 0,334 & 0.418 \\
\hline Perspektif Bisnis Internal & 0,418 & 0,335 \\
\hline Total & 2,422 & 2,34 \\
\hline
\end{tabular}

Dari data diatas menunjukkan perspektif keuangan mengalami penurunan dari 0,835 menjadi 0,752. Hal tersebut menunjukkan jika performa keuangan pada PrintPro mengalami penurunan performa.

Sedangkan untuk perspektif pelanggan pun memiliki kinerja yang cenderung konstan. Hal tersebut dikarenakan nilai skor pada perspektif ini menunjukkan pada tahun 2014 dengan nilai 0,84 dan pada tahun 2015 dengan nilai 0,84 juga. 
Untuk perspektif pembelajaran dan pertumbuhan mengalami kenaikan dari 0,334 dan 0,418 . Hal tersebut menunjukkan adanya kenaikan performa yang bisa diambil dari kinerja yang semakin baik pada setiap tahunnya.

Dan untuk terakhir dari perspektif bisnis internal mengalami penurunan dari tahun 2014 ke tahun 2015. Dari perspektif ini menunjukkan nilai 0,418 menjadi 0,335.

Jika dilihat lebih detil, aspek yang mengalami penurunan secara umum adalah ROI, dan tingkat penjualan produk baru. Dengan demikian, perusahaan harus memprioritaskan perbaikan pada peningkatan nilai ROI dan tingkat penjualan produk baru. Terutama nilai ROI yang merupakan aspek dari perspektif keuangan, karena tujuan utama dari perusahaan ini berbasis pada profit yang dihasilkan.

\subsection{Usulan Perbaikan Kinerja Perusahaan}

Usulan yang diberikan merupakan usulan yang dapat diimplementasikan sebagai langkah perbaikan karena kinerja perusahaan mengalami penurunan. Penurunan tersebut harus segera diperbaiki hingga kinerja semakin meningkat dan bisa mencapai target yang sudah ditentukan.

Perspektif Financial

A. Perspektif Financial

Pada perspektif financial terdapat KPI yang belum memenuhi target, dan terdapat juga yang mengalami penurunan. Dua KPI yang menjadi sorotan adalah Operating Ratio dan Rate on Invesment. Untuk meningkatkan kedua KPI tersebut adalah dengan usulan sebagai berikut:

- Meningkatkan pendapatan dengan upaya pemasaran. melalui peningkatan inovasi produk

- Melakukan efisiensi produksi pada setiap mesin produksi yang digunakan

- Melakukan pengembangan dan perbaikan fasilitas dan pelayanan yang telah dihasilkan untuk meningkatkan pendapatan, sehingga dapat mengoptimalkan sumber daya yang ada untuk mencapai pendapatan yang optimal

B. Perspektif Pelanggan

- Sebisa mungkin menghindari produk defect dengan begitu kualitas produk yang dihasilkan.

- Menjaga hubungan yang baik dengan customer.

- Memberikan penawaran yang menarik (potongan harga) bagi pelanggan

C. Perspektif Bisnis Internal

- Meningkatkan inovasi produk melalui menambah desain produk.

D. Perspektif Pembelajaran dan Pertumbuhan

- Menanggapi keluhan karyawan dengan baik, sehingga loyalitas karyawan dapat meningkat.

- Menjaga komunikasi yang baik dengan karyawan.

\section{Kesimpulan dan Saran}

Secara umum, penilaian kinerja perusahaan PrintPro dengan menggunakan metode Balance Scorecard sudah menunjukkan hasil yang positif dan konsisten. Identifikasi dari pencapaian Critical Succes Factor (CSF) untuk setiap perspektif sudah baik. Hanya saja pada perspektif financial dan bisnis internal mengalami penurunan. Pada aspek financial, penurunan disebabkan oleh nilai ROI yang mengalami penurunan. Pada perspektif Pelanggan cenderung konstan dan tidak mengalami kenaikan atau pun penurunan. Untuk dari perspektif Bisnis internal, mengalami penurunan dikarenakan jumlah produk baru yang diluncurkan pada tahun 2015 sangat sedikit, sehingga mengalami penurunan yang cukup signifikan.

Sedangkan dari perspektif pembelajaran dan pertumbuhan, mengalami kenaikan karena dari segi retensi karyawan mengalami kenaikan yang artinya karyawan yang keluar lebih sedikit pada tahun 2015.

Usulan yang diberikan pada setiap perspektif financial adalah dengan meningkatkan pendapatan dengan upaya pemasaran. melalui peningkatan inovasi produk, melakukan efisiensi produksi pada setiap mesin produksi yang digunakan, melakukan pengembangan dan perbaikan 
fasilitas dan pelayanan yang telah dihasilkan untuk meningkatkan pendapatan, sehingga dapat mengoptimalkan sumber daya yang ada untuk mencapai pendapatan yang optimal.

Untuk perspektif pelanggan diberikan usulan berupa sebisa mungkin menghindari produk defect dengan begitu kualitas produk yang dihasilkan, menjaga hubungan yang baik dengan customer dan memberikan penawaran yang menarik (potongan harga) bagi pelanggan,

Sedangkan untuk perspektif bisnis internal diberikan usulan berupa meningkatkan inovasi produk melalui menambah desain produk dan menjalin serta menjaga hubungan yang baik dengan supplier. Dan untuk perspektif pembelajaran dan pertumbuhan diberikan usulan berupa menanggapi keluhan karyawan dengan baik, sehingga loyalitas karyawan dapat meningkat, dan menjaga komunikasi yang baik dengan karyawan.

Penelitian lanjutan pada perusahaan ini, dapat melakukan Standar Operasional Prosedur untuk setiap kegiatan. Hal tersebut, dikarenakan pada perusahaan ini belum diterapkan SOP yang jelas.

\section{Daftar Pustaka}

Hanuma, Soraya.(2011).Analisis Balance Scorecard Sebagai Alat Pengukur Kinerja Perusahaan. Eprint Undip.

Hidayat, Rachmat, Utami, Issa Dyah, dan Umayya. (2010). Tolok Ukur Penilaian Kinerja Badan Usaha Dengan Balanced Scorecard (BSC), Jurnal Teknologi, Vol. 3, No.2: 90-98

Nugraha, Aditya.(2014). Balanced Scorecard Analysis As Coorporate Performance Measurement Case Study PT PLN Persero Area Malang, diakses pada 23 Desember 2015, dari http://jimfeb.ub.ac.id/index.php/jimfeb/article/viewFile/1207/1114.

Nurjaman, Sidik.(2013). Pengukuran Kinerja dengan Metode Balanced Scorecard, Trikonomika, Vol.2: 113-124

Prasetiyanto, Rachmat Hidayat dan Utami, Issa Dyah. (2011). Pengukuran Kinerja Perusahaan dengan Metode Balanced Scorecard, Performa, Vol.10, No.2: 71-82

Rusdiyanto, Ahmad Falah. (2010). Analisis Kinerja dengan Pendekatan Balanced Scorecard Pada PDAM Kabupaten Semarang, Jurnal Undip.

Raharja, Untung, Yusup, Muhamad, dan Rosyifa, Eva. (2012).Optimalisasi Key Performance Indicators (KPI) Melalui Pendekatan Balanced Scorecard Upaya Mengimplementasikan Performance Management System (PMS) pada Perguruan Tinggi.

Rushton, Alan, dkk. (2006). The Handbook of Logistics and Distribution Management $3^{\text {rd }}$ edition,United Kingdom, Bell and Bain, Glasgow

Singgih, Moses L, dkk. (2001). Pengukuran dan Analisa Kinerja Dengan Metode Balanced Scorecard di PT. “X”, Jurnal Teknik Industri, Vol.3, No.2, Desember 2001: 48-56 